\title{
Study of Pre-service Primary Teachers' Professional Identity in Yunnan Qujing Normal University of China
}

\author{
Qin Gao \\ Dept. Early Child Development \\ Teacher Education College \\ Qujing Normal University \\ Qujing, China
}

\begin{abstract}
This study contributes to the existing teacher education on teacher professional identity, particularly in response to curriculum and instruction, motivation, future job choice and professional development. It proposes to offer a much better understanding of how pre-service primary teachers' professional identities have evolved through their school, motivation and perception, and the tensions they experience associated with their beliefs about teaching and learning and their actual practice. Specifically, this study aims to identify how teachers' professional identities have evolved following curriculum and instruction in department of primary education at Yunnan Qujing Normal University of China. 400 students participated this study including 100 freshman, 90 sophomore, 100 junior, and 110 senior at Qujing Normal University in spring, 2015. This finding indicated that college curriculum quality related with their job selecting as a factor affecting job. This finding implied their perception of pre-service training as a factor affecting professional identities.
\end{abstract}

Keywords-primary education; professional identities; preservice teacher

\section{INTRODUCTION}

Teachers are important influences on what children can achieve in school. Empirical research indicates that student achievement depends on the teachers they have, regardless of child background [1] [2] [3] [4]. Teacher educators have been challenged that construction of an individual, meaningful, resilient professional identity. Understanding early pre-service teachers' emerging identity may enable teacher educators to prepare pre-service teachers for their teaching career, through facilitating the development of a professional identity as teachers, and eventually the development of effective teachers who thrive in the profession.

\section{STATEMENT OF PURPOSE}

It is important to investigate student teachers' authentic voices at the outset of professional education. The objective of this study is to investigate professional identities of preservice primary school teachers in one rural Normal University in Yunnan province, China; the students enrolled this class were at least 3-year experience in teaching around this region. How do beginning pre-service teachers understand themselves as the teacher and how do they present themselves in a drawing of the teacher they aspire to be before they undertake field work in school? How do their identities in curriculum and instruction? Do they have a clear vision of themselves and the kind of teacher they will become? Specifically, the research question guiding the present study was: How do pre-service primary school teachers graphically represent the teacher they hope to become? Drawings were used as a method of data collection to enable insight into how beginning pre-service primary school teachers envision themselves as the teacher. In choosing drawing as the method for collecting data about pre-service primary school teachers' understandings of themselves as the teacher, we acknowledge that the drawings will not necessarily be works of art in themselves.

\section{RELATED STUDIES}

In earlier literature, the concept of identity was often vaguely described in terms of the self and one's self-concept [5] [6]. From this perspective, identity of the self is seen to be established and maintained either through negotiation within social situations, or through social roles that are internalized by the individuals (Wah Tan, 1997) [7] [8]. Identity can generally be denned as who or what someone is, the various meanings people can attach to themselves, or the meanings attributed by others [9]. Nowadays, identity formation is conceived as an ongoing process that involves the interpretation and reinterpretation of experiences as one lives through them [10]. Through self-evaluation, one's identity is continually informed, formed, and reformed as individuals develop over time and through interaction with others [11]. Both self-evaluation and identity are part of one's self-image. Nias [12] wrote that people feel threatened when they face changes that influence their self-image and, consequently, their personal identity. To cope with such changes, people often develop strategies as a protection against being forced to perceive them in another way. Nonetheless, people are able to further develop, adjust, or even radically change their self-image. There are no reasons 
to assume that teachers are exceptions to this rule. Up till now, little research has been done on teachers' professional identity and, except for so called life-cycle' research [13] [14], the way they develop this identity. However, some research attempts are being undertaken now, in most cases this research lacks a clear dentition of a teacher's professional identity [15]. In an earlier research project, it attempted to define this identity on the basis of three distinctive categories, namely: the subject one teaches, the relationship with students, and the teacher's role or role conception. Subsequently, each category could be divided into a number of subcategories. For each subcategory, teachers were asked to clarify their actual perceptions and prior experiences. This research has led to some interesting results, such as changes found in relevant features of teachers' professional identity as a result of experiences and contextual influences, but it appeared to be difficult for teachers to focus on each subcategory separately. With regard to some subcategories, teachers also found it difficult to clarify their perceptions, which seem to convict with the relevance they attached to the subcategories as representations of their professional identity. Apparently, several of these categories appeared to be taken for granted by them and immune from refection. Against the background of these research experiences, we reconsidered relevant categories that cover a teacher's professional identity. As it was inspired by the work, the following statement became the starting point of this research: teachers derive their professional identity from (mostly combinations of) the ways they see themselves as subject matter experts, pedagogical experts, and didactical experts.

\section{Methodology}

The research was conducted in Yunnan Qujing Normal University after obtaining the necessary ethical approval. Participants received an information letter explaining the purpose of the research and that the submission of the drawings was not related to any assessments in the course. It was assumed that if drawings were handed in that consent was given to include these in the study. Participants were given the option to identify their drawing which would allow for future data collection.

\section{A. Data Collecting Procedures}

The study were 400 students, including 100 freshman, 90 sophomore, 100 junior, and 110 senior at Qujing Normal University in spring, 2015. Participants in the full study were students in several sessions of the course. All students required to participate in all classroom activities, to complete assignments and learning activities to meet course requirement, middle term exam, and final exam from the beginning of the spring semester to the end of the spring semester within 18 weeks "Table I". "Table II" Shows the information that all participants' awareness in curriculum or what the primary education in undergraduate. This focus was on how participants at Qujing Normal University perceive their professional identity. The findings figured 33 freshman (33\%), 31 sophomore (34.5\%), 28 junior (28\%), and 24 senior $(22 \%)$ of the participants not to identify primary teachers subject before entering college.

TABLE I. BACKGROUND OF CHARACTERISTICS OF PARTICIPANTS

\begin{tabular}{|l|l|l|}
\hline \multicolumn{1}{|c|}{ Degree } & \multicolumn{1}{|c|}{ Number } & \multicolumn{1}{c|}{ Percentage (\%) } \\
\hline Freshman & 100 & 25 \\
\hline Sophomore & 90 & 22.5 \\
\hline Junior & 100 & 25 \\
\hline Senior & 110 & 27.5 \\
\hline Total & 400 & 100 \\
\hline
\end{tabular}

TABLE II. PERCENTAGE OF PARTICIPANTS’ IDENTITIES IN PRIMARY DEPARTEMT BEFORE UNDERGRADUATE

\begin{tabular}{|l|l|l|l|l|}
\hline & \multicolumn{2}{|c|}{ Never } & \multicolumn{2}{c|}{ Ever } \\
\hline Degree & Number & $\begin{array}{c}\text { Percentage } \\
(\%)\end{array}$ & Number & Percentage (\%) \\
\hline Freshman & 33 & 33 & 67 & 67 \\
\hline Sophomore & 31 & 34.5 & 59 & 65.5 \\
\hline Junior & 28 & 28 & 72 & 72 \\
\hline Senior & 24 & 22 & 86 & 78 \\
\hline
\end{tabular}

\section{B. Validity and Reliability}

The reliability coefficient of an instrument is generally measured by Cronbach's $\boldsymbol{\alpha}$. High correlation between alternative survey items or large Cronbach's $\boldsymbol{\alpha}(>0.70)$, are usually indications that the survey items are indeed reliable. Cronbach's Alpha value for all questionnaire items was 0.898 , indicating strong reliability.

\section{RESEARCH FINDINGS}

The purpose of this study is to investigate professional identities of pre-service primary school teachers. The professional identities of this study was assessed in several ways, such as participating students' initial identities before entering college, motivation of participating students' in primary school subject selecting, participating students' professional identities in primary education curriculum, and in service teacher professional with occupation choice.

\section{A. Students' Motivation in Primary School Profession}

"Table III" figured the motivation of participants' choice in department of school education. $74(18.4 \%)$ by self , 104 $(26 \%)$ by parents and friends, $216(54 \%)$ by score factor, and $6(1.6 \%)$ by other factors showed that score factor is an important element of professional identity in motivation, meaning that teachers' original active performance in the process of professional development. This element professional identity formation is in line with a constructivist view of learning, which means that learning-individually as well as in collaboration - takes place through the activity of the learner. But, the figure showed that at least $54 \%$ participants depending on score factor in selecting primary school education subject. 
TABLE III. Motivation In Primary School Education SELECTING

\begin{tabular}{|l|l|l|}
\hline \multicolumn{1}{|c|}{ Motivation } & \multicolumn{1}{|c|}{ Frequency } & \multicolumn{1}{c|}{ Percentage (\%) } \\
\hline Self & 74 & 18.4 \\
\hline Parents and Friends & 104 & 26 \\
\hline Scores & 216 & 54 \\
\hline Other & 6 & 1.6 \\
\hline Total & 400 & 100 \\
\hline
\end{tabular}

\section{B. Perception of Curriculum and Instruction}

Curriculum and instruction was identified as a crucial attribute for all professionals in the teaching enterprise. Every university teacher was expected to be knowledgeable and competent in not only the content of their specialized subject matter but also the pedagogical aspect. This finding is, indeed, in line with what other scholars indicate as knowledge base resulting from education or training in particular period in a recognized institution with approved curricula. The perception of primary school context may likely benefit students in the future as they make decisions about selecting between the different educational or training options for themselves or those they manage. The study responses clearly shows that the majority of students have notably sufficient knowledge and experience with profession. Such as $11.2 \%$ in perfect participants, $20 \%$ in bad participants, $6.4 \%$ in worse participants of students are unfamiliar with theory from primary school education. This suggests that most students in this study rated curriculum and instruction quite low, and they were also quite low in their ratings of satisfaction with skills course, the last item of the questionnaire "Table IV".

TABLE IV. PERVEPTIPN OF CURRICULUM AND INSTRUCTION

\begin{tabular}{|l|l|l|l|l|l|l|l|l|}
\hline & \multicolumn{2}{|c|}{ Perfect } & \multicolumn{2}{c|}{ Good } & \multicolumn{2}{c|}{ Bad } & \multicolumn{2}{c|}{ Worse } \\
\hline \multicolumn{1}{|c|}{ Instruction } & Frequency & Percentage (\%) & Frequency & Percentage (\%) & Frequency & Percentage (\%) & Frequency & Percentage (\%) \\
\hline Theory & 45 & 11.2 & 250 & 62.4 & 80 & 20 & 25 & 6.4 \\
\hline Skills & 22 & 5.2 & 233 & 58.7 & 127 & 31.6 & 18 & 4.5 \\
\hline Practice & 214 & 53.7 & 138 & 34.6 & 25 & 6.1 & 23 & 5.6 \\
\hline
\end{tabular}

\section{Future Job Selection}

This part of questions addresses the issue on how students perceive their future job selecting. In the data analysis, the majority, at least $58 \%$, of students believe that primary school teacher outline is very good after they graduate from college. And at least $58.1 \%$ will choose primary school teacher as their first choice after they graduate from college. But, still 14.6 participants and $4.3 \%$ one will choose as government workers and other jobs respectively. "Table V" and "Table VI"

TABLE V. FUTUR VISION IN JOB ABOUT PRIMARY SCHOOL EDUCATION

\begin{tabular}{|l|l|l|}
\hline \multicolumn{1}{|c|}{ Perception } & \multicolumn{1}{c|}{ Frequency } & \multicolumn{1}{c|}{ Percentage (\%) } \\
\hline Very Good & 232 & 58 \\
\hline Good & 84 & 21 \\
\hline Not Good & 56 & 14 \\
\hline Bad & 28 & 7 \\
\hline Total & 400 & 100 \\
\hline
\end{tabular}

TABLE VI. PARTICIPANTS' FUtURE JOB CHOICE

\begin{tabular}{|l|l|l|}
\hline \multicolumn{1}{|c|}{ Job } & \multicolumn{1}{c|}{ Frequency } & \multicolumn{1}{c|}{ Percentage (\%) } \\
\hline Primary Teacher & 233 & 58.1 \\
\hline Graduate School & 92 & 23 \\
\hline Government Worker & 59 & 14.6 \\
\hline Others & 16 & 4.3 \\
\hline Total & 400 & 100 \\
\hline
\end{tabular}

This finding indicated that there is no apparent significant difference between college curriculum quality and their job selecting as a factor affecting job. This finding implied their perception of pre-service training as a factor affecting professional identities. This result agrees with the finding of Ewen who reported that categorically that teachers" professional identities is directly linked with the quality and quantity of training and career opportunities provided.

\section{CONCLUSION}

There is little question that teachers are an important influences on what children can achieve in school. Empirical research indicates that student achievement depends on the teachers they have, regardless of child background (. In fact, some research suggests that differences in teacher quality account for more variation in student achievement than any other school-related influence. The use of drawings has enabled an exploration of pre-service teachers' professional identity. The findings of the study indicate further questions to be answered in relation to the process. Identity is contextual and shaped by interplay of the personal and the contextual, with potential conflict, for example, between the personal and the professional. Pre-service teachers in other studies have reported a tension between the expectations of the school and the university and that the teacher they want to be is not valued in a school . For teacher educators, an important role could be one of supporting pre-service teachers to develop the awareness that the image they have of themselves and the reality of the classroom could be different. The examination of drawings by both pre-service teachers and educators may provide an appropriate way forward to understand the reality of the work of teachers. Similarly, pre-service teachers could be made aware of the supportive and practical role that other adults play in the resilience of pre-service and early career teachers in discussions about the content of drawings. There are many complexities involved in developing a teacher identity. Using drawings enabled them to depict key aspects of themselves as future teachers. Identity is shaped by both personal and contextual factors, but there seemed to be no hint of potential future challenges that might destabilize these individuals' positive emotions as they encounter the realities of teaching . Also, in rural China, this results carry important policy implications for teacher recruitment, retention, and professional development. Thus, it raises important questions 
about how to make teaching a desirable profession, particularly.

\section{ACKNOWLEDGMENT}

This research is support by Yunnan Province Social Science Grant.

\section{REFERENCES}

[1] Goldhaber, D., Brewer, D., Anderson, D. 1999. A Three-way Error Components Analysis ofEducational Productivity Education Economics, 7 (3), 199-208.

[2] Rivkin, S.G., Hanushek, E.A., Kain, J.F. 2005. Teachers, schools, and academic achievement.Econometrica 73 (2), 417-458

[3] Murnane, R.J., Phillips, B. 1981. Learning by Doing, Vintage, and Selection: Three Pieces of the Puzzle Relating Teaching Experience and Teaching Performance. Economics of Education Review 1 (4), 453-465.

[4] McEwan, P. 1991. Recruitment of rural teachers in developing countries: an economic analysis. Teaching and Teacher Education, 15, 849-859.

[5] Ewen, B.R. (1974). Determinants of Job Satisfaction: A Study of the Generality of Herberg's Theory. Journal of applied psychology pp. 162

[6] Klecker, B. \& Loadman, W. (2011). Exploring the Relationship Between Teachers' Empowerment and Teachers Job Satisfaction \|. Midwestern Educational Research Association.

[7] Beattie, M. (2000). Narratives of professional learning: Becoming a teacher and learning to teach. Journal of Educational Enquiry, 1 (2), $1-23$.

[8] Beauchamp, C. \& Thomas, L. (2009). Understanding teacher identity: An overview of issues in the literature and implications for teacher education. Cambridge Journal of Education, 39 (2), 175-189.

[9] Beijaard, D., Meijer, P. C. \& Verloop, N. (2004). Reconsidering research on teachers' professional identity. Teaching and Teacher Education, 20 (2), 107-128.

[10] Britzman, D. P. (2003). Practice makes practice: A critical study of learning to teach. (Revised Edition). Albany: State University of New York Press.

[11] Coughlin, M. (2001). See teacher draw: Exploring pre service teachers' perceptions of teaching. Academic Exchange Quarterly, 5 (3), 191-195.

[12] Czerniawski, G. (2011). Emerging teachers - emerging identities: Trust and accountability in the construction of newly qualified teachers in Norway, Germany, and England. European Journal of Teacher Education, 34 (4), 431-447.

[13] Day, C. \& Gu, Q. (2014). The role of resilience in teachers' careerlong commitment and effectiveness: Evidence from the field. In C. Day \& Q. Gu (Eds.), Resilient teachers,resilient schools (pp. 120-134).

[14] Hong, J. Y. (2010). Pre-service and beginning teachers' professional identity and itsrelation to dropping out of the profession. Teaching and Teacher Education, 26 (8), 1530-1543.

[15] Moore, A. (2004). The good teacher: Dominant discourses in teaching and teacher education. New York: Routledge. 